\title{
ROLE OF DIETARY IODINE ON MODULATING PRODUCTIVE, REPRODUCTIVE, PHYSIOLOGICAL AND IMMUNOLOGICAL PERFORMANCE FOR LOCAL CHICKENS 2-DURING LAYING PERIOD
}

M. M. Soliman ${ }^{1 *}$; S.F.Hassaan ${ }^{1}$; H. A. H. Abd El-Halim ${ }^{1}$; and Sahar, M.H. Osman ${ }^{2}$

${ }^{1}$ Dep.of Poult.Breed. Res. ${ }^{2}$ Dep.of Poult. Breed.Nut. Res.Anim. Prod. Res.Inst., Agric. Res. Center, Dokki, Giza

Corresponding author: Mohamed Soliman; dr.mohamed.soliman066@ gmail.com

Received: $03 / 01 / 2018$

Accepted: $29 / 01 / 2018$

ABSTRACT: This experiment was conducted for a complex period of 24 wks (each of 12 wks, respectively) to investigate the effect of adding different dietary levels of iodine as calcium iodide $\left(\mathrm{CaI}_{2}\right)$ on modulating some productive, reproductive and physiological parameters of Inshas strain (Egyptian developed strain). For this purpose 150 laying hens and 15 males ( 36 until 48 wks of age) were taken from a large flock in the $2^{\text {nd }}$ period after finishing the $1^{\text {st }}$ period (24-36 wks of age) that used in recording the egg production only and then divided into five equal treatment groups, each of 30 females and 3 males, with three equal replicates nearly similar in live body weight. The $1^{\text {st }}$ group (T1) represented the overall mean of egg production of the flock and fed the basal diet $(0.3 \mathrm{mg}$ iodine $/ \mathrm{kg}$ diet $)$ and served as control 1, the other four groups were having an average egg production less than the overall mean by $20 \%$. Hens were divided as follows, the $2^{\text {nd }}$ group (T2) was fed the basal diet and served as control 2, while the $3^{\text {rd }}(\mathrm{T} 3)$, the $4^{\text {th }}(\mathrm{T} 4)$ and the $5^{\text {th }}(\mathrm{T} 5)$ groups were fed the basal diet plus 1.2, 2.4 and $4.8 \mathrm{mg}$ iodine $/ \mathrm{kg}$ diet, respectively. Results indicated that iodine supplementation especially at 4.8 followed by $2.4 \mathrm{mg}$ iodine $/ \mathrm{kg}$ diet non significantly improved feed conversion ratio ( $\mathrm{g}$ feed/g egg) and egg mass, while shell thickness was significantly $(\mathrm{P} \leq 0.05)$ improved compared to the control 2 group. Egg number and production percentage were significantly $(\mathrm{P} \leq 0.05)$ improved by iodine supplementation at $4.8 \mathrm{mg}$ iodine/kg diet (T5 group) compared to the control 2 group. Moreover, significant increases were obtained for red and white blood cells count. As well, plasma total protein, albumin, globulin, $\mathrm{T}_{3}$ and $\mathrm{T}_{4}$ hormones, calcium and phosphorus salts and HDL-Ch were elevated significantly $(\mathrm{P} \leq 0.05)$ at $4.8 \mathrm{mg}$ iodine $/ \mathrm{kg}$ diet. Conversely, additional iodine especially (T5 group) reduced significantly plasma concentration of total lipid, cholesterol, LDL-Ch. On the other hand, T4 and T5 groups recorded the highest values of fertility and hatchability percentage of Inshas hens.

In conclusion, dietary addition of iodine as $\mathrm{CaI}_{2}$ is a practical application at $4.8 \mathrm{mg} \mathrm{I} / \mathrm{kg}$ diet to Inshas hens and had beneficial effects on productive, reproductive, physiological and hematological parameters and immune status.

Keywords: Iodine, productive, reproductive, physiological, Inshas strain. 


\section{INTRODUCTION}

Iodine is recognized as one of the essential elements for poultry and is normally provided in the diet in its free form, or as an iodate or iodide, which is essentially required for birds in small amounts for normal production and metabolic functions (Patrick, 2008). It plays a great physiological role as a component of the thyroid hormones (thyroxin and triiodothyronine) which involved in the regulation of both anabolic and catabolic pathways of protein, lipid and carbohydrate metabolism, (Lewis, 2004 and Nima et al., 2012). Calcium iodide is a white crystal line powder with a minimum content of $63 \%$ total iodine and $10 \%$ calcium, (Eurl, 2012). Rottger et al. (2011) compared various levels of iodine supplementation $(0,1.0,2.5$ and $5.0 \mathrm{mg}$ $\mathrm{I} / \mathrm{kg}$ feed) from two sources (potassium and calcium iodide) and they did not show any adverse effect on chickens performance and thyroid weight of chickens. Saki et al. (2012) concluded that egg production can be obtained by 5 and $10 \mathrm{mg} \mathrm{CaI} / \mathrm{kg}$ diet without any adversely effects. El-Wardany et al. (2011) showed that administration of $1 \mathrm{mg} \mathrm{CaI} / 2 / \mathrm{kg}$ chickens diet could improve the productive performance compared with the control diet in association with considerable changes in thyroidal hormones $\left(\mathrm{T}_{3}\right.$ and $\left.\mathrm{T}_{4}\right)$ and their ratio. Moreover, their results reflect the beneficial use of $\mathrm{CaI}_{2}$ as a safe additive without hazards effects on organs histology. Likewise, Abdel-Malak et al. (2012) reported that egg production and feed conversion ratio of Golden Montazah laying hens recorded the best values for hens which fed diet containing 1.2 and $2.4 \mathrm{mg} \mathrm{I} / \mathrm{kg}$ diet, also blood thyroid hormones, calcium and phosphorus were significantly increased by increasing iodine levels. On the other hand, thyroid hormones are implicated in the reproduction of birds and hyperthyroidism improved hatchability as reported by El-Sebai et al. (2002). Additionally, El-Ansary et al. (1996) reported that administration of $\mathrm{KI}$ in drinking water at level of 400ppm increased $(\mathrm{P} \leq 0.05)$ feed conversion, egg production, weight and mass. Moreover, Ibrahim, et al. (2015) found that performance (egg production and egg mass), hatchability percent, feed conversion ratio improved by increasing iodine level up to $2.4 \mathrm{mg}$ iodine $/ \mathrm{kg}$ diet as compared with control diet in Sinai laying hens. They added that dietary iodine supplementation, up to $2.4 \mathrm{mg} / \mathrm{kg}$ diet improved blood parameters, hematological traits, $\mathrm{T}_{3}$ level, and $\mathrm{T}_{3} / \mathrm{T}_{4}$ ratio without negative effects on liver function and immune responses, interms of ALT, AST activity and WBC's count.

Therefore, the objectives of this experiment were to study the influence of varying dietary levels of iodine on some productive, reproductive performance, some physiological and hematological parameters, and immune status of local laying hens (Inshas strain) during the laying period (36-48 wks of age).

\section{MATERIALS AND METHODS}

This study was carried out at Inshas Poultry Research Station (El-Sharkia Governorate), Animal Production Research Institute, Agricultural Research Center, Egypt.

\section{Chickens and experimental design}

A total number of 150 hens and 15 cocks 24 wks old of Inshas strain were used in this experiment up to $48 \mathrm{wks}$ of age through two continuance periods each of $12 \mathrm{wks}$, the $1^{\text {st }}$ period from 2436 wks of age was used in recording the 
Iodine, productive, reproductive, physiological, Inshas strain

egg production only and then the birds were individually weighted and divided into 5 equal experimental groups (30 hens and 3 cocks of each) with three replicates (10 hens and 1 cock each) with almost similar average body weight. Replicates were randomly housed in floor pens $(280 \mathrm{~cm}$ long $\mathrm{X}$ $220 \mathrm{~cm}$ wide). The $1^{\text {st }}$ group (T1) represented the overall mean egg production of the hens flock during the periods from 24-36 wks of age and fed the basal diet contained $0.3 \mathrm{mg}$ iodine $/ \mathrm{kg}$ diet and served as control 1 . The other four groups were taken from the same flock with an average egg production less than the overall mean by $20 \%$. Hens were divided on treatments as follows, the $2^{\text {nd }}$ group (T2) was fed the basal diet and served as control 2, while the $3^{\text {rd }}(\mathrm{T} 3)$, the $4^{\text {th }}(\mathrm{T} 4)$ and the $5^{\text {th }}$ (T5) groups were fed the basal diet supplemented with $\mathrm{CaI}_{2}$ to get 1.2, 2.4 and $4.8 \mathrm{mg}$ iodine $/ \mathrm{kg}$ diet, respectively.

\section{Management and feeding:-}

All birds were kept under the same managerial hygienic and environmental conditions in a windowed house with light cycle regimen of $16 \mathrm{~h}$ light: $8 \mathrm{~h}$ darkness, throughout the experimental period. Feed and fresh water were provided ad libitum. The basal experimental diet was formulated to meet the nutrient requirements of Inshas laying hens during laying period according to Feed composition Tables for animal and poultry feed stuffs used in Egypt (2001). The composition and calculated analysis of the experimental basal diet is present in Table 1.

\section{Measurements:-}

\section{Productive performance:-}

Individual body weights of all birds was recorded two times at 36 and 48 wks of age to the nearest gram. Change in live body weight was calculated as the difference between the two weights. Feed consumption was recorded weekly for each replicate and treatment group and the average feed consumption/bird/day was calculated. Feed conversion ratio was calculated as gram feed consumed per gram egg production (g feed/g egg). Individual egg weight and egg number were recorded daily, then average egg mass and egg production percentage were calculated for each replicate and treatment. Egg mass was calculate by multiplying egg number by average egg weight.

\section{Egg quality parameters:-}

At the last two days of experiment, eight freshly laid eggs per replicate were collected to evaluate external and internal egg quality as egg length and width were measured by a venire caliper to the nearest 0.01 millimeter and egg shape index was estimated. Egg shell quality was assessed where the eggs were weighed individually, broken and egg contents were removed, egg shells with membranes were cleaned and dried. Egg shell weight and percentage of whole egg were determined. Egg shell thickness (mm) was determined also. Records were also taken for albumen weight, height and weight. Also, yolk weight, height, diameter and index were estimated.

Blood biochemical analysis and hematological picture:-

At 48 wks of age two blood samples were collected from each replicate from the wing vein in two heparinized test tubes. Blood of the first tube was used to evaluate the total count of red and white blood cells, and blood smears were done and stained with leishman's stain for the differential counts of 
M. M. Soliman ${ }^{1}$ et al.

leucocytes. Another blood tube was centrifuged at $3000 \mathrm{rpm}$ for $15 \mathrm{~min}$, so plasma samples were harvested and stored at $-20^{\circ} \mathrm{C}$ until the biochemical analysis was done. Commercial kits were used for calorimetrically determination of the following blood plasma constituents according to the procedure out lined by the manufacturer. Total protein and albumin, calcium and inorganic phosphorus, total lipids, total cholesterol, high density lipoproteins (HDL), low density lipoproteins (LDL), and hepatic enzymes aspartate amino transaminase (AST) and alanine amino transaminase (ALT) were determined. Globulin was calculated by subtraction of plasma albumin from total protein, and albumin/globulin ratio was calculated. Concentration of plasma triiodothyronine $\left(\mathrm{T}_{3}\right)$ and thyroxin $\left(\mathrm{T}_{4}\right)$ hormones were determined using commercial enzyme immunoassay test kit.

\section{Fertility and hatchability:}

At 48 weeks of age, each treatment contained 3 replicates, each replicate contains of 10 hens and 1 cock. The cocks and hens were placed on the floor and supplied with the same treatments. Eggs from each treatment were daily collected for two weeks, and then incubated to determine fertility percentage and hatchability was calculated as a percentage of fertile eggs or of total eggs set.

\section{Statistical analysis:}

Data were subjected to one-way analysis of variance using general linear models (GLM) procedure of SAS, Institute (2001). Means were separated by using Duncan's multiple range test (Duncan, 1955). The percentage values were transferred to percentage angle using arcsine equation before subjected to statistical analysis, and then actual means are presented.

The following model was used: $\mathrm{Y}_{\mathrm{ij}}=\mathrm{G}+\mathrm{T}_{\mathrm{i}}+\mathrm{e}_{\mathrm{ij}}$.

Where, $Y_{i j}=$ observation for each dependent variable; $\mathrm{G}=$ General mean; $\mathrm{T}_{\mathrm{i}}=$ Treatment effects $(\mathrm{i}=1,2 \ldots$ and 5$)$; $\mathrm{e}_{\mathrm{ij}}=$ Random error.

\section{RESULTS AND DISCUSSION Productive performance traits: Body weight and body weight gain:}

Results obtained from Table 2 indicated that the dietary inclusion of iodine as $\mathrm{CaI}_{2}$ improved the final body weight and body weight gain at the end of the experimental period compared with the control 2 group (T2) especially hens fed on T4 or T5 group. These results are in full agreement with those reported by Hassaan et al. (2015) who found that values of body weight and body weight gain were improved significantly $(\mathrm{P} \leq 0.01)$ due to iodine supplementation especially at 4.8 followed by $2.4 \mathrm{mg}$ iodine $/ \mathrm{kg}$ diet compared with control group. Similar to results of the current study, Ibrahim et al. (2015) reported that body weight and body weight gain were significantly improved by increasing iodine level at $2.4 \mathrm{mg} \mathrm{I} / \mathrm{kg}$ diet compared with the control diet in Sinai laying hens. Likewise, these results are in agreement with those reported in foreign chicken by El-Ansary et al. (1996) who demonstrated that addition of KI to the diet increased $(\mathrm{P} \leq 0.05)$ the body weight and body weight gain of the hens comparing to control group. Also, El-Wardany et al. (2011) in broilers, Soliman et al. (2008) and Abdel-Malak et al. (2012) in local chickens found an improvement body weight and body weight gain using 
Iodine, productive, reproductive, physiological, Inshas strain

graded levels of dietary iodine. The increase in final body weight and body weight gain of Inshas laying hens during the experimental period especially T5 group may be due to the increase in thyroid hormones $\left(\mathrm{T}_{3}\right.$ and $\left.\mathrm{T}_{4}\right)$ which are needed for normal growth and development as reported here in Table 6. Thyroid hormones are necessary with growth hormone for growth and development, which involved in the insulin-like growth factor (IGF1) production, stimulating cellular protein synthesis in almost every tissue of body throughout the life of chickens (Tsukada et al., 1995).

\section{Laying performance:}

Data concerning laying performance in Table 2 showed a non-significant differences among iodine treatment groups for feed intake values but feed conversion ratio (g feed/g egg) was slightly improved by the diet containing $4.8 \mathrm{mg} \mathrm{I} / \mathrm{kg}$ diet (T5 group) as compared to the control 2 group. On the other hand, laying performance parameters (egg number, production $\%$ and mass) were significantly improved in the hens fed diet contains 4.8 and $2.4 \mathrm{mg} \mathrm{CaI} / 2 \mathrm{~kg}$ diet respectively compared with those in the control 2 group. These findings are consistent with the findings of El-Ansary et al. (1996) in chicken and Hamdy and Abdel-Latif (1999) in Japanese quail, who reported an improvement in feed conversion ratio due to dietary or drinking water supplemented with KI. Also, El-Wardany et al. (2011) in broiler, Soliman et al. (2008), Abdel-Malak et al. (2012) and Ibrahim et al. (2015) in local chickens reported that, addition of $1 \mathrm{mg}$ $\mathrm{CaI}_{2}$ or $0.80 \mathrm{~mm}$ or 1.2 and $2.4 \mathrm{mg} \mathrm{I} / \mathrm{kg}$ diet respectively improved the feed conversion ratio as well as improved significantly egg number, mass and production\% compared with the control group. The influence of iodine on feed utilization may be due to an alteration of the microflora of the gut, consequently, more nutrients are available for better growth performance of chicks (Stanley and Bailey, 1989). It's worthy to note that the better FCR may be due to the increase in body weight gain that achieved during the whole experiment period. The improvement in the egg production performance may be associated with better metabolizability of nutrients by $\mathrm{CaI}_{2}$ supplementation. The beneficial effect of dietary $\mathrm{CaI}_{2}$ on egg production parameters is due to its role on modulating the rate of intestinal calcium absorption, therefore saving more calcium for egg production (AbdelHamid et al., 2000).

\section{Egg quality:}

Concerning external and internal egg quality traits, Table 3 showed that hens fed on diets provided with 4.8 and $2.4 \mathrm{mg}$ $\mathrm{I} / \mathrm{kg}$ diet respectively slightly improved egg length and width, albumen height, albumen (\%), yolk height and yolk diameter. As well as improved significantly $(\mathrm{P} \leq 0.05)$ shell thickness as compared with the hens in the control 2 group. These results agreed with the findings of Soliman et al. (2008), Madian (2008), and Ibrahim et al. (2015) who reported that external egg quality especially shell thickness and internal egg quality especially albumen and yolk height were significantly improved when they supplementation iodine from $0.48 \mathrm{mg}$ to $2.4 \mathrm{mg} \mathrm{I} / \mathrm{kg}$ diet for local chickens. Abdel-Hamid et al. (2000) reported that the beneficial effect of dietary $\mathrm{CaI}_{2}$ on external egg quality is due to its role on enhance $\mathrm{Ca}$ absorption through the gut, therefore saving more $\mathrm{Ca}$ for egg production and external egg quality. 
M. M. Soliman ${ }^{1}$ et al.

\section{Hemato-biochemical parameters:} Hematological characteristics:

The results showed that iodine treated had significantly $(\mathrm{P} \leq 0.01)$ high $\mathrm{Red}$ blood cells (RBC's) number and White blood cells count (WBC's) especially $\mathrm{T} 5$ and $\mathrm{T} 4$ that fed 4.8 or $2.4 \mathrm{mg} \quad \mathrm{I} / \mathrm{kg}$ diet respectively (Table 4). These results comes in agreement with the previous findings of El-Nagar et al. (2001) on broiler chicken, Abaza et al. (2003) on Alexandria cockerels, Ibrahim et al. (2015) and Hassaan et al. (2015) on local chicken, they reported that RBC's number was significantly increased with dietary iodine supplementation from 2.4 to $4.8 \mathrm{mg} \mathrm{I} / \mathrm{kg}$ diet (hyperthyroidism), which was accompanied by a significant increase in hemoglobin and heamatocrite concentration. As well as WBC's count was significantly increased $(\mathrm{P} \leq 0.05)$ in chicken fed diet containing 2.4 or $4.8 \mathrm{mg}$ $\mathrm{I} / \mathrm{kg}$ diet compared with the control 1 group. This mainly, due to an increase in the lymphocyte percentage. In spite of, the absence of significance among treatments respecting the $\mathrm{H} / \mathrm{L}$ ratio, it is observable that the $\mathrm{CaI}_{2}$ groups had numerically low values compared with the non supplemented ones, indicating better immune responses. This comes in good agreement with the findings of Abaza et al. (2003) who stated a positive correlation between thyroxin levels and number of circulating lymphocytes.

\section{Biochemical characteristics:}

Data of some blood plasma constituent of Inshas laying hens at 48 wks of age as affected by fed diets containing varying levels of iodine $\left(\mathrm{CaI}_{2}\right)$ are presented in Table 5. Plasma total protein, albumin, globulin and albumin/globulin ratio, it is evidently shown that dietary supplementation of iodine has been increased $(\mathrm{P} \leq 0.05)$ the average values of both plasma total protein, albumin and globulin levels especially for T5 and T4 groups, respectively. These results are in close agreement with those reported by Hassaan et al. (2015) and Ibrahim et al. (2015) in local laying hens they revealed a significant high levels of all protein fractions in hens that fed the higher level of iodine 4.8 followed by $2.4 \mathrm{mg} \mathrm{I} / \mathrm{kg}$ diet compared with the control one $(0.3 \mathrm{mg} / \mathrm{kg})$. This influence may be due to the ability of iodine to stimulate protein synthesis and or nitrogen retention. Of interest, the albumin/ globulin ratio has been well known as an indicator for the immune resistance, was the highest in the untreated hens $\mathrm{T} 1$ and $\mathrm{T} 2$ controls indicating the worst immune status. Where the low albumin/ globulin ratio indicate more disease resistance and immune response (Lee et al., 2003). It is clear that the effect of iodine supplementation was more pronounced in laying hens received the high level of iodine $(4.8 \mathrm{mg} \mathrm{I} / \mathrm{kg}$ diet), thus plasma total lipids concentration was decreased significantly. Moreover, plasma cholesterol, triglycerides and LDL followed the same trend as plasma total lipids. On the contrary, plasma level of HDL was significantly $(\mathrm{P} \leq 0.05)$ high for the iodine supplemented groups comparable to the control groups. These results are in agreement with the finding of El-Nagar et al. (2001), El-Sebai et al. (2002), Hassaan et al. (2015) and Ibrahim et al. (2015) who reported that plasma total lipids, triglycerides and cholesterol were significantly decreased under hyperthyroidism status or addition of $\mathrm{CaI}_{2}$ by 4.8 or $2.4 \mathrm{mg} / \mathrm{kg}$ diet, respectively. The previous results confirm the concept of the relationship between thyroid gland activity and lipid metabolism. These results may be due to the role of thyroid 
Iodine, productive, reproductive, physiological, Inshas strain

hormones or iodine dietary levels which considered the main factors affecting lipid metabolism in laying hens as reported by Mcnabb and King (1993), Bobiniene et al. (2010) and El-Wardany et al. (2011).

Respecting the influence of supplemental dietary iodine on plasma concentration of calcium and phosphorus, results shown in Table 5 revealed that, non supplemented control groups had significantly the lowest plasma concentration of both minerals ( $\mathrm{Ca}$ and $\mathrm{P}$ ) when compared to the other supplemented ones. Besides, calcium and phosphorus levels were increased in plasma of lying hens whose fed diet contained the high level of iodine (T5 group) followed by those in T4 and $\mathrm{T} 3$ groups respectively. These results are in harmony with El-Sebai et al. (2002), Soliman et al. (2008), and Hassaan et al. (2015) who reported that both plasma $\mathrm{Ca}$ and $\mathrm{P}$ concentrations increased under hyperthyroidism or adding high levels of iodine as $\mathrm{CaI}_{2}$ at levels from 0.80 to $4.8 \mathrm{mg} / \mathrm{kg}$ diet. This may be attributed to the differences in $\mathrm{Ca}$ and $\mathrm{P}$ regulation and absorption among the experimental groups. As well, thyroid hormones increased the total $\mathrm{Ca}$ and $\mathrm{P}$ absorption efficiency (Abdel-Hamid et al., 2000).

\section{Thyroid activity and liver functions:}

Data presented in Table 6, illustrate the effect of dietary iodine supplementation on thyroid gland activity and liver functions of Inshas laying hens. Plasma concentrations of thyroid hormones $\left(\mathrm{T}_{3}\right.$ and $\mathrm{T}_{4}$ ), as an indication of thyroid activity, were significantly increased $(\mathrm{P} \leq 0.05)$ by increasing dietary iodine levels compared with the control groups (T1 and T2), which recorded the lowest levels of both hormones. These results agreed with El-Wardany et al. (2011) in broilers, Hassaan et al. (2015) in local cockerels, Soliman et al. (2008), AbdelMalak et al. (2012) and Ibrahim et al. (2015) in local laying hens by adding $\mathrm{CaI}_{2} 1 \mathrm{mg} / \mathrm{kg}$ diet or different levels of iodine $(0.6,0.8,1.2,2.4$ and 4.8$) \mathrm{mg} / \mathrm{kg}$ diet respectively. They showed that thyroid hormones were significantly increased by increasing iodine levels. The current results showed that plasma concentration of $\mathrm{T}_{3}$ hormone was significantly elevated in the heavy and high production group compared to the light and low ones. It is likely that when iodine was supplemented to the diet, it could increase blood plasma $T_{3}$ and the $\mathrm{T}_{3} / \mathrm{T}_{4}$ ratio in a dose dependent manner. This is a good physiological response as $\mathrm{T}_{3}$ was the most potent thyroid hormone in regulating all metabolic processes in living mammals and birds. Moreover, the enhanced $T_{3} / T_{4}$ ratio reflects an increase in the peripheral turnover of $\mathrm{T}_{4}$ to $_{3}$ via deiodination process in the presence of excess dietary iodine. These effects may explain the improvements in egg production and quality traits of the laying hens in the present study. This suggestion was supported by the previous findings of several studies conducted by Hayashi et al. (1992), El-Husseiny et al. (2000), Bobiniene et al. (2010) and Miskiniene et al. (2010).

It is clearly observed that, dietary addition of iodine levels, (Table 6) could significantly affect the hepatic enzymes activities. Where, Inshas laying hens of control groups recorded the highest values of both aspartate amino transaminase (AST) and alanine amino transaminase (ALT) enzymes comparable to laying hens of the other supplemented groups. These results indicated that supplemental iodine had no deleterious effect on liver functions and may protect the hepatocytes of Inshas laying hens 
M. M. Soliman ${ }^{1}$ et al.

from being destroyed and that is meant a better liver function associated with iodine supplementation. The current results are in harmony with El-Nagar et al. (2001) in broiler chicks, El-Sebai et al. (2002) in Japanese quail, Hassaan et al. (2015) in local cockerels and Ibrahim et al. (2015) in local laying hens. They found that serum AST and ALT concentration were significantly decreased with hyperthyroidism or addition of dietary iodine. Therefore, the results indicated that the heavy body weight and high egg production treated laying hens had a better liver functions than the light and low ones. These results are in harmony with those of Hassaan et al. (2009) who reported that light weight and low production chicks on the average produce the lowest meat and egg mass, because this class would include mainly more unhealthy chicks than the heavy and high production birds, which confirm the results of the present study.

\section{Fertility and hatchability:-}

All the dietary iodine supplementations significantly $(\mathrm{P} \leq 0.05)$ improved the fertility and hatchability of fertile eggs percentages compared with those of control groups (Table 7). Moreover, the best significant $(\mathrm{P} \leq 0.05)$ result of hatchability of all eggs recorded by Inshas laying hens fed diet supplemented with $4.8 \mathrm{mg} \mathrm{I} / \mathrm{kg}$ diet compared with control 1 group. The improvement in hatchability percentages could be attributed to the improvement in egg shell quality in quail (Mostafa and AbdelMageed, 2006). These results agreed with El-Sebaie et al. (2002) in Japanese quail, Soliman et al. (2008) and Ibrahim et al. (2015) in local laying hens by feeding laying hens on diets containing iodine salts as calcium iodine at levels $(0.48$, 0.80 and $2.4 \mathrm{mg} / \mathrm{kg}$ diet) improved percentage of fertility, hatchability of total and fertile eggs and shell thickness compared to the control groups. This finding is in good agreement with the findings of Mcnabb et al. (1985) who reported that in Japanese quail, maternal diets containing $150 \mu \mathrm{g} \mathrm{I} / \mathrm{kg}$ diet can improve hatchability by providing sufficient egg I for the thyroid function of embryos and hatchlings.

\section{IN CONCLUSION,}

the present study indicated that supplemental iodine especially at level $4.8 \mathrm{mg} \mathrm{I} / \mathrm{kg}$ diet as $\mathrm{CaI}_{2}$ to Inshas laying hens of $-20 \%$ from the overall mean egg production, could improve productive and reproductive performance, as well as physiological, hematological and immunological parameters for attaining the goal of improvement of egg production in local and developed Egyptian laying hens. 
Table (1): The composition of the experimental basal diets.

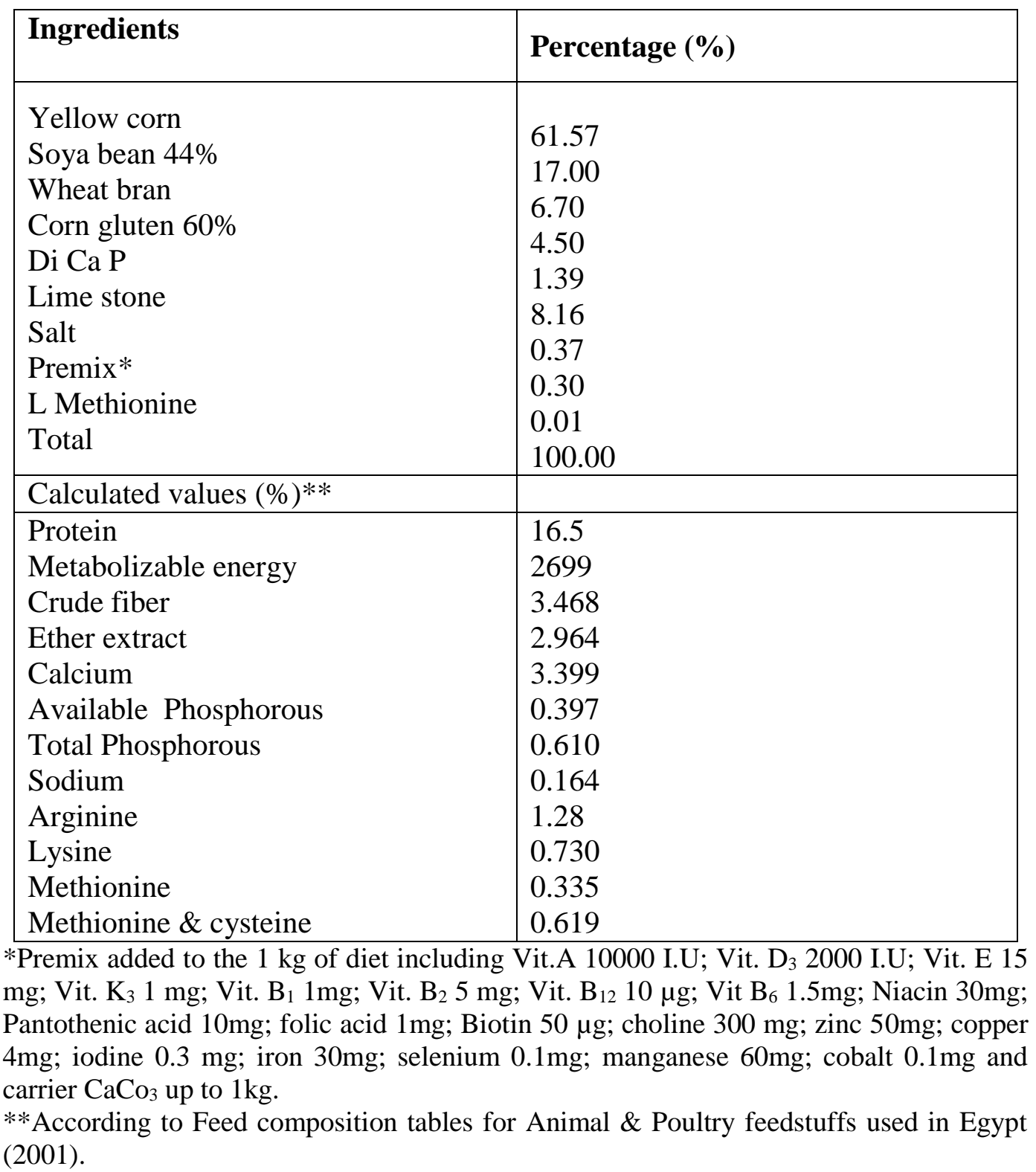


Table (2): Effect of dietary iodine supplementation on the performance of Inshas laying hens during the experimental period.

\begin{tabular}{|l|l|l|l|l|l|l|}
\hline Item & T1 & T2 & T3 & T4 & T5 & SE \\
\hline Initial body weight (g) & 1352 & 1341 & 1338 & 11341 & 1338 & 9.002 \\
Final body weight (g) & 1477 & 1459 & 1456 & 472 & 1475 & 10.675 \\
Change in body weight (g) & 125 & 118 & 118 & 131 & 137 & 12.818 \\
Feed intake (g/hen/day) & 97.30 & 97.88 & 98.12 & 96.80 & 97.60 & 0.459 \\
Total feed intake (g/hen/period) & 8173.20 & 8221.92 & 8242.08 & 8131.20 & 8198.40 & 38.582 \\
Feed conversion (g feed/g egg) & $3.31^{\mathrm{b}}$ & $3.88^{\mathrm{a}}$ & $3.79^{\mathrm{a}}$ & $3.63^{\mathrm{ab}}$ & $3.52^{\mathrm{ab}}$ & 0.112 \\
Egg number (egg) & $49.58^{\mathrm{a}}$ & $41.43^{\mathrm{c}}$ & $42.99^{\mathrm{bc}}$ & $44.85^{\mathrm{abc}}$ & $46.86^{\mathrm{ab}}$ & 1.491 \\
Egg production (\%) & $59.02^{\mathrm{a}}$ & $49.32^{\mathrm{c}}$ & $51.17^{\mathrm{bc}}$ & $53.39^{\mathrm{abc}}$ & $55.79^{\mathrm{ab}}$ & 1.776 \\
Egg weight (g) & 49.93 & 51.11 & 50.60 & 50.34 & 49.71 & 0.618 \\
Egg mass (g) & $2476.03^{\mathrm{a}}$ & $2117.19^{\mathrm{b}}$ & $2173.89^{\mathrm{b}}$ & $2257.75^{\mathrm{ab}}$ & $2328.86^{\mathrm{ab}}$ & 75.291 \\
\hline
\end{tabular}

$8 \quad \mathrm{a}, \mathrm{b} \ldots$.... Means within each row have no similar letter(s) are significantly different $(\mathrm{P} \leq 0.05)$

$\mathrm{T} 1=$ Control 1 group, T2=Control 2 group, T3=Fed the basal diet $+1.2 \mathrm{mg}$ iodine $/ \mathrm{kg}$ diet, T4=Fed the basal diet $+2.4 \mathrm{mg}$ iodine $/ \mathrm{kg}$ diet, T5=Fed the basal diet $+4.8 \mathrm{mg}$ iodine $/ \mathrm{kg}$ diet. 
Table (3): Effect of dietary iodine supplementation on external and internal egg quality of Inshas laying hens at 48 weeks of age.

\begin{tabular}{|c|c|c|c|c|c|c|}
\hline Item & T1 & T2 & T3 & T4 & T5 & SE \\
\hline \multicolumn{7}{|l|}{ External egg quality } \\
\hline Egg length (mm) & $53.69^{\mathrm{a}}$ & $52.03^{\mathrm{ab}}$ & $51.96^{\mathrm{b}}$ & $52.51^{\mathrm{ab}}$ & $53.29^{\mathrm{ab}}$ & 0.543 \\
\hline Egg width (mm) & 41.30 & 41.19 & 40.37 & 40.90 & 41.14 & 0.382 \\
\hline Shell thickness (mm) & $0.371^{\mathrm{b}}$ & $0.368^{\mathrm{b}}$ & $0.372^{\mathrm{ab}}$ & $0.374^{\mathrm{a}}$ & $0.377^{\mathrm{a}}$ & 0.003 \\
\hline Shell weight (\%) & 13.06 & 14.25 & 13.68 & 14.25 & 13.39 & 0.596 \\
\hline Egg shape index & 76.97 & 79.21 & 77.74 & 77.92 & 77.24 & 0.742 \\
\hline \multicolumn{7}{|l|}{ Internal egg quality } \\
\hline Albumen height (mm) & 6.89 & 7.04 & 7.04 & 6.58 & 7.14 & 0.541 \\
\hline Albumen (\%) & 56.29 & 53.42 & 54.48 & 54.22 & 55.20 & 0.987 \\
\hline Yolk height (mm) & 17.06 & 17.08 & 16.41 & 16.70 & 16.96 & 0.308 \\
\hline Yolk diameter & 39.15 & 38.52 & 38.81 & 38.66 & 39.76 & 0.524 \\
\hline Yolk (\%) & 30.66 & 32.33 & 31.84 & 31.53 & 31.42 & 0.686 \\
\hline Yolk index & 43.65 & 44.39 & 42.37 & 43.26 & 42.75 & 0.963 \\
\hline
\end{tabular}

a, b.... Means within each row have no similar letter(s) are significantly different $(\mathrm{P} \leq 0.05)$

Table (4): Effect of dietary iodine supplementation on hematological picture of Inshas laying hens at 48 weeks of age.

\begin{tabular}{|l|l|l|l|l|l|l|}
\hline Item & T1 & T2 & T3 & T4 & T5 & SE \\
\hline Red blood cells (x 10 $/ \mathrm{ul})$ & $2.910^{\mathrm{d}}$ & $3.110^{\mathrm{cd}}$ & $3.232^{\mathrm{bc}}$ & $3.352^{\mathrm{ab}}$ & $3.494^{\mathrm{a}}$ & 0.069 \\
White blood cells (x 10\%) & $26.896^{\mathrm{c}}$ & $29.566^{\mathrm{bc}}$ & $32.132^{\mathrm{ab}}$ & $35.006^{\mathrm{a}}$ & $35.490^{\mathrm{a}}$ & 1.170 \\
Heterophil (\%) & 29.066 & 28.552 & 28.484 & 26.882 & 27.282 & 1.845 \\
Lymphocyte (\%) & 60.196 & 63.412 & 63.562 & 62.588 & 63.704 & 1.390 \\
Heterophil/Lymphocyte ratio & 0.486 & 0.451 & 0.449 & 0.430 & 0.429 & 0.030 \\
\hline
\end{tabular}

a, $\ldots \ldots .$. Means within each row have no similar letter(s) are significantly different $(\mathrm{P} \leq 0.05)$ 
Table (5): Effect of dietary iodine supplementation on blood plasma proteins, lipids and minerals concentrations of Inshas laying hens at 48 weeks of ages.

\begin{tabular}{|c|c|c|c|c|c|c|}
\hline Item & T1 & T2 & T3 & T4 & T5 & SE \\
\hline \multicolumn{7}{|l|}{ Plasma proteins: } \\
\hline Total protein $(\mathrm{g} / \mathrm{dl})$ & $4.78^{c}$ & $5.22^{\mathrm{bc}}$ & $5.17^{\mathrm{bc}}$ & $5.65^{\mathrm{ab}}$ & $5.85^{\mathrm{a}}$ & 0.169 \\
\hline Albumin $(\mathrm{Al})(\mathrm{g} / \mathrm{dl})$ & $2.74^{\mathrm{b}}$ & $3.05^{\mathrm{a}}$ & $2.93^{\mathrm{ab}}$ & $3.14^{\mathrm{a}}$ & $3.18^{\mathrm{a}}$ & 0.079 \\
\hline Globulin $(\mathrm{Gl})(\mathrm{g} / \mathrm{dl})$ & $2.04^{\mathrm{c}}$ & $2.18^{\mathrm{bc}}$ & $2.24^{\mathrm{abc}}$ & $2.51^{\mathrm{ab}}$ & $2.67^{\mathrm{a}}$ & 0.139 \\
\hline Al/Gl Ratio & 1.354 & 1.414 & 1.328 & 1.276 & 1.214 & 0.083 \\
\hline \multicolumn{7}{|l|}{ Plasma lipids: } \\
\hline Total lipids (mg/dl) & $418.27^{\mathrm{a}}$ & $389.37^{\mathrm{ab}}$ & $387.16^{\mathrm{ab}}$ & $356.40^{b}$ & $347.14^{b}$ & 13.796 \\
\hline Total cholesterol (mg/dl) & $182.01^{\mathrm{a}}$ & $158.89^{a b}$ & $140.14^{\mathrm{bc}}$ & $133.28^{\mathrm{bc}}$ & $123.69^{c}$ & 10.131 \\
\hline Triglycerides $(\mathrm{mg} / \mathrm{dl})$ & $96.10^{\mathrm{a}}$ & $82.75^{b}$ & $76.44^{\mathrm{bc}}$ & $72.00^{\mathrm{bc}}$ & $66.97^{c}$ & 4.209 \\
\hline HDL-ch (mg/dl) & $62.67^{\mathrm{c}}$ & $71.03^{b}$ & $75.20^{\mathrm{ab}}$ & $79.40^{\mathrm{ab}}$ & $83.39^{\mathrm{a}}$ & 2.743 \\
\hline LDL-ch (mg/dl) & $100.11^{\mathrm{a}}$ & $71.31^{\mathrm{ab}}$ & $49.65^{b c}$ & $39.47^{b c}$ & $26.91^{\mathrm{c}}$ & 11.141 \\
\hline \multicolumn{7}{|l|}{ Plasma minerals: } \\
\hline Calcium (mg/dl) & $9.02^{c}$ & $9.90^{\mathrm{bc}}$ & $10.98^{a b}$ & $11.36^{\mathrm{ab}}$ & $11.64^{\mathrm{a}}$ & 0.493 \\
\hline Phosphorus (mg/dl) & $4.77^{\mathrm{d}}$ & $5.05^{\mathrm{d}}$ & $6.03^{c}$ & $7.16^{b}$ & $7.80^{\mathrm{a}}$ & 0.237 \\
\hline
\end{tabular}

a, b.... Means within each row have no similar letter(s) are significantly different $(\mathrm{P} \leq 0.05)$ 
Table (6): Effect of dietary iodine supplementation on thyroid activity and liver functions of Inshas laying hens at 48 weeks of ages.

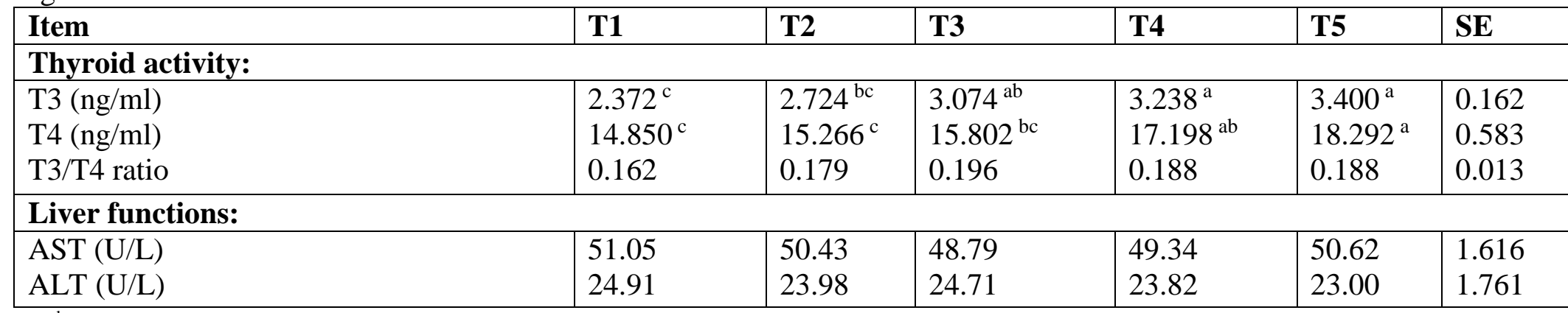

a, b.... Means within each row have no similar letter(s) are significantly different $(\mathrm{P} \leq 0.05)$

Table (7): Effect of dietary iodine supplementation on fertility and hatchability percentages of Inshas laying hens at 48 weeks of ages.

\begin{tabular}{|c|c|c|c|c|c|c|}
\hline Item & T1 & $\mathbf{T 2}$ & T3 & T4 & T5 & SE \\
\hline Fertility (\%) & $84.54^{c}$ & $85.94^{b c}$ & $90.62^{\mathrm{a}}$ & $93.00^{\mathrm{a}}$ & $92.04^{\mathrm{a}}$ & 1.349 \\
\hline Hatchability of all eggs (\%) & $80.30^{\mathrm{b}}$ & $82.91^{\mathrm{ab}}$ & $82.83^{\mathrm{ab}}$ & $83.67^{\mathrm{ab}}$ & $85.00^{\mathrm{a}}$ & 1.325 \\
\hline Hatchability of fertile eggs $(\%)$ & $83.17^{b}$ & $84.21^{b}$ & $88.19^{\mathrm{a}}$ & $91.15^{\mathrm{a}}$ & $90.33^{\mathrm{a}}$ & 1.809 \\
\hline
\end{tabular}

a, b.... Means within each row have no similar letter(s) are significantly different $(\mathrm{P} \leq 0.05)$ 
M. M. Soliman ${ }^{1}$ et al.

\section{REFERENCES}

Abaza, M.; El-Nagar, S.; And El-Sebai, A. 2003. Thyroid effects on semen quality and immune responses of mature Alexandria cockerels. Egypt. Poult. Sci., 23: 721-736.

Abdel-Hamid, E. F.; Hussein, H. M.; and El-Wardany, I. E. 2000. Calcium and Phosphorus absorption as related to thyroxine and estrogen administration in two local strains of laying hens. Egypt J. Appl.Sci.,15:3355.

Abdel-Malak, N. Y.; Osman, Sahar, M. H.; Bahakaim, A. S. A.; Omar, A.S.; and Ramadan, Nehad, A. 2012. Effect of using different levels of iodine in layer's diets on egg iodine enrichment. Egypt. Poult. Sci., 32:851-864.

Bobiniene, R.; Gudavicute, D.; and Miskiniene, M. 2010. The impact of iodine on biochemical blood parameters in laying hens. Vet. Med. Zootech, 51 (73):3-9.

Duncan, D. B. 1955. Multiple range and multiple F-tests. Biometrics, 11: 1-42.

El-Ansary, E.; El-Sharawy, G. E.; and Zaki El-Din, M. 1996. Effect of iodine on the growth rate of chicks and egg production of hens. Egypt. Poult. Sci., 16:513-533.

El-Husseiny, O. M., Arafa, S. A., Hashish, S. M. and Madian, A. H. H. 2000. Response of broiler performance to triiodothyronine (T3), thyroxin (T4), iodocasein and thiouracil supplemented diets. Egypt. Poult. Sci., 20:347-371.

El-Nagar, Samar; El-Sebai, Azza; and Abaza, M. 2001. Manipulation of thyroidal activity in broiler chicks: I.Birds Performance, Physiological and biochemical observations. Egypt. Poult. Sci., 21:1101-1119.
El-Sebai, Azza; Abaza, M. A.; and ElNagar, Samar, A. 2002. Relationship between thyroid gland and some reproductive and physiological traits of Japanese quail reared under short day photoperiod. Egypt. Poult. Sci., 22:519-530.

El-Wardany, I.; El-Daly, Eman, F.; Abd El-Gawad, A. H.; Hemid, A. E. A.; and Abd El-Azeem, Nafisa, A. 2011. Effect of thyroid activity modulation on some histological and biochemical aspects in broiler chickens. American-Eurasian J. Agric. and Environ. Sci., 11(6):893-902.

Eurl, 2012. Report on potassium iodine and calcium iodate anhydrous. Europen commission, feed additives. No. 454413.

Feed Composition Tables for Animal and Poultry Feedstuffs Used in Egypt 2001. Technical Bulletion No.1, Central lab for Feed and Food; Ministry of Agriculture, Egypt.

Hamdy, A. M. M.; and Abd El-Latif, S. A. 1999. Effect of iodinated water on some productive and metabolic parameters of Japanese quail hens. Proceedings of the $6^{\text {th }}$ scientific conferences on Anim. Nutr., 19-21 October, El-Arish, Egypt Part II. Egypt. J. of Nutr. and Feeds: Special issue, 703.

Hassaan, S. F.; Abdel-Fattah, S. A.; Elsalmony, A. E.; and Hassan, M. S. H. 2009. Relationship between some serum enzyme activities, liver function and body weight in growing local chickens. Inter. J. Poult. Sci., 8 (7):700-705.

Hassaan, S. F.; Soliman, M. M.; and Sahar, M. Osman 2015. Role of dietary iodine on modulating productive, reproductive, 
Iodine, productive, reproductive, physiological, Inshas strain

physiological and immunological performance in local chickens 1During growth period. Egypt. Poult. Sci., 35:991-1008.

Hayashi, K.; Keneda, S.; Orsuka, A.; and Tomita, Y. 1992. Effect of ambient temperature and thyroxin on protein turnover and oxygen consumption in chicken skeletal muscle. Proceeding IX World's Poultry Congress. Vol. 2, Amsterdam, The Netherlands, 20-24.

Ibrahim, A. F.; Beshara, M. M.; and Hanan, S. Mohamed 2015. Effect of iodine supplementation low energy diets on productive and reproductive performance in laying hens of local Sinai strain. J. Animal and Poultry Production, Mansoura Univ., 6:122158.

Lee, D. N.; Cheng, F. Y.; Line, R. S.; and Wu, P. C. 2003. Effect of dietary chromium picolinate supplementation on growth performance and immune responses of broilers. Asian Austr. J. Anim. Sci., 16:227-233.

Lewis, P. D. 2004. Responses of domestic fowl to excess iodine: a review. British Journal of Nutrition, 91:29-39.

Madian, A. H. 2008. Effect of dietary iodine some productive and metabolic responses of local laying hens. Egypt. Poult. Sci., 28:19-34.

McNabb, F. M.; Dicken, S. G.; and Cherry, J. C. 1985. The effects of different maternal dietary iodine concentration on Japaness quail coturnix japonica. Domestic Animal Endocrinology. 2:35-42.

McNabb, F. M.; and King, D. B. 1993. Thyroid hormone effects on growth, development and metabolism.In.: The Endocrinology of Growth,
Development, and metabolism in Vertebrates,Academic press, New York , PP.393-417.

Miskiniene, M.; Inga, K.; Rasa, B.; Gudavicate, D.; and Eider, J. 2010. Application of "JODIS" as a stable source of iodine in the nutrition of laying hens. Bull. Vet. Inst. Pulawy, 54:389-392.

Mostafa, Kout El-Kloub, M.; and Abdel-Mageed, M. A. 2006. Effect of dietary levels of calcium and vitamin D3and their interactions on the performance of Japanese quail chicks. Egypt. Poult. Sci., 26:967-989.

Nima, E.; Hamed, A.; Mahmud, S.; AbolFazl, Z.; and Niloofar, A. 2012. Effect of different calcium iodate levels on performance, carcass traits and concentration of thyroid hormone in broiler chickens. Annals of Biolo. Res., 3: 2223 - 2227.

Patrick, L. 2008. Iodine deficiency and therapeutic considerations. Altern Med. 13 (2): 116.

Rotteger, A. S.; Halle, I.; Wanger, H.; Breves, G.; and Flachowsky, G. 2011. The effect of various iodine supplementation and two different iodine sources on performance and iodine concentrations in different tissues of broilers. Brit. Poult. Sci., 52, 115-123.

Saki, A. A.; Aslani, M.; Aliarabi, H.; Zamani, P.; and Abbasinezhad, $M$. 2012. Iodine-enriched egg production in response to dietary iodine in laying hens. Journal of Agric. Technology Vol. 8 (4):1255-1267.

SAS institute, 2001. SAS Users Guide Statistics Version $10^{\text {th }}$, 16- Edition, SAS Inst., Cary, NC.

Soliman, M. M.; Alm El-Dein, A. K.; Awaden, N. B.; and Rezaa, A.M. 
M. M. Soliman ${ }^{1}$ et al.

2008. Effect of using iodine salts on thyroid activity, physiological and productive performance of laying hens 1-During the first 90 days of egg production in the first generation. Egypt. J. of Appl. Sci., 23:12-24.

Stanley, V.G.; and Bailey, J. E. 1989.

Effect of iodine treated water on the performance of broiler chickens reared under various stocking densities. Poult. Sci., 68:435.

Tsukada, A.; Okhubo, T.; Sakaguchi, K.; Tanaka, M.; and Hoshino, S. 1995. Thyroid hormones are involved in insulin like growth factor (IGF1) production by regulating growth hormone receptor in the chicken. Poult. and Avian biology Reviews, 6No. 4:303. 
Iodine, productive, reproductive, physiological, Inshas strain

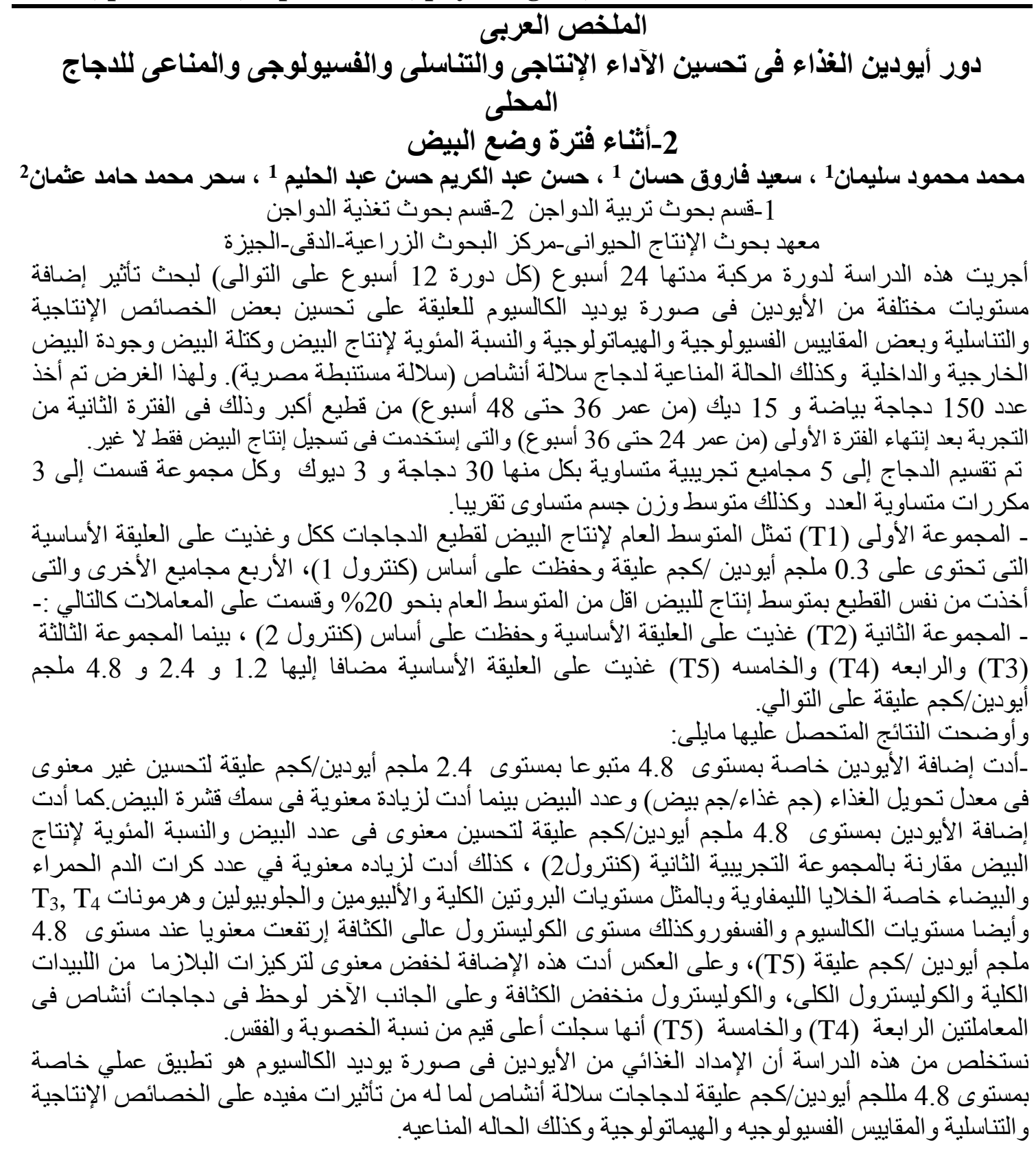

